\title{
Application of the Speech Handicap Index on Patients with Parkinson's Disease
}

\author{
Hyo Jin Mun ${ }^{\mathrm{a}}$, Sung-Rae Cho ${ }^{\mathrm{b}}$, Seong Hee Choi ${ }^{\mathrm{c}}$, HyangHee Kimo ${ }^{\mathrm{a}, \mathrm{b}}$ \\ ${ }^{a}$ Graduate Program in Speech and Language Pathology, Yonsei University, Seoul, Korea \\ ${ }^{b}$ Department and Research Institute of Rehabilitation Medicine, Yonsei University College of Medicine, Seoul, Korea \\ 'Department of Audiology and Speech-Language Pathology, Catholic University of Daegu, Gyeongsan, Korea
}

\author{
Correspondence: HyangHee Kim, PhD \\ Graduate Program in Speech and Language \\ Pathology, Yonsei University, 50-1 Yonsei-ro, \\ Seodaemun-gu, Seoul 03722, Korea \\ Tel: +82-2-2228-3902 \\ Fax: +82-2-2227-7984 \\ E-mail: h.kim@yonsei.ac.kr
}

Received: January 7, 2018

Revised: February 6, 2018

Accepted: February 12, 2018

\begin{abstract}
Objectives: Speech problems are commonly seen in patients with Parkinson's disease (PD). The problems incurred by PD patients lead to a feeling of dissatisfaction and incompetence, causing a deteriorated quality of life. However, to date, there is no assessment tool to evaluate the self-perception of speech problems in PD patients. Thus, this study aims to look into the self-perception of speech problems in patients with PD. Methods: Forty-eight PD patients (men 20, women 28) were administered the Speech Handicap Index (SHI). Also, we analyzed the relationship between $\mathrm{SHI}$ and speech intelligibility and other variables, while looking into factors affecting the results of $\mathrm{SHI}$ by using multiple regression analysis. Results: Most of the PD patients scored higher than the average scores of the normal controls from the previous study, indicating a high degree of self-perception of their own speech problems. The current study also revealed that SHI scores are negatively related to speech intelligibility while positively related to depression and severity of disease. In addition, multiple regression analysis has shown that speech intelligibility and depression are two factors affecting SHI. Conclusion: The study is significant in that it is the first study that identified the self-perception of speech problems in PD using the SHI. The fact that patients in H\&Y stages I or II demonstrated high SHI scores would imply that careful attention should be given to speech problems of PD patients from early stages of the disease.
\end{abstract}

Keywords: Speech Handicap Index (SHI), Parkinson's disease, Quality of life, Speech intelligibility, Depression, H\&Y stage
파킨슨병 환자는 중추 혹은 말초 신경계의 손상으로 인해 말운 동 기관의 근육 조절 어려움으로 마비말장애가 나타난다(Hartelius \& Svensson, 1994). 마비말장애 하위 유형 중에서도 운동저하형 마비말장애(hypokinetic dysarthria)로서 단음도와 단음량, 강세저 하, 말 속도변이, 짧은 말뭉침(short rushes of speech), 자음오류, 거 칠고 쉰 음성 등의 말 특징을 보인다. 이 결함들은 환자의 말명료도 (speech intelligibility)를 저하시키고 다른 사람들과의 의사소통에 어려움을 준다(Darley, Aronson, \& Brown, 1969). 이들의 말명료도 는 문장 수준에서 정상인에 비해 $85 \%$ 로 저하되어 있고, 배경 소음 이 있을 경우에는 53\%로 더욱 저하되었다(Ferguson, 2012). 파킨슨 병 환자의 말명료도는 청자에게 부정적인 인상을 주며, 낮은 말명 료도로 인해 의사소통과 사회적 상호작용의 기회를 제한한다(Jay- want \& Pell, 2010). ASHA의 삶의 질 척도 연구에서도 파킨슨병 환 자는 낮은 말명료도로 인해 삶의 질이 저하되었다(Dykstra, Hakel, \& Adams, 2007).

최근 들어, 환자들의 삶의 질에 대한 관심이 증가함에 따라 환자 중심의 평가(patient-based outcomes)가 중요해졌다(Den Oudsten, Van Heck, \& De Vries, 2007). 파킨슨병 환자의 일반적인 삶의 질에 대한 연구에서 환자의 신체적 증상, 신경심리학적 증상, 임상적 증 상, 정신적 증상과 의사소통 능력이 삶에 질에 중대한 영향을 미쳤 다(Sapir, 2014). 파킨슨병 환자의 삶의 질에 대한 다양한 연구가 이 루어지고 있지만, 일반적인 삶의 질에만 집중되어 있고 의사소통 능 력을 고려한 연구는 부족하다(Miller, Noble, Jones, \& Burn, 2006). 특히, 의사소통 능력에 대한 연구가 있다고 하더라도 음성(voice)에 
만 집중되어 있고 파킨슨병 환자의 주요 증상인 말(speech)문제에 특화된 환자 중심의 평가에 관해서는 존재하지 않는다. 말 문제는 대부분의 파킨슨병 환자들에게 나타나고 환자들 스스로 인식하므 로 중요한 요소이다(Duffy, 2013). 파킨슨병 환자들은 주로 말이 너 무 빠르다거나 발음이 부정확하여 대화 참여에 제한을 받는다고 호소한다(Plowman-Prine et al., 2009). 또한 그들이 말 문제로 인 해 분노, 좌절감, 무능감 등의 감정을 느끼고 의사소통에 제한을 받 고 있기에 그에 대한 평가가 더욱 필요하다(Jaywant \& Pell, 2010). 이처럼 말 문제에 대해서는 환자 호소 중심의 사례만 있을 뿐 말 문 제에 특화된 삶의 질에 대한 연구는 부족한 실정이다. 그러므로 자 기보고 형식의 말장애지수(SHI)를 통해 연구의 폭을 넓힐 수 있다.

$\mathrm{SHI}$ 는 원래 두경부암 환자를 위해 개발되었고 일상생활에 환자 의 말이 미치는 영향을 보고하는 설문지이다(Rinkel, Leeuw, van Reij, Aaronson, \& Leemans, 2008). 이 도구는 네덜란드어로 개발되 었고, 영어, 프랑스어, 중국어 등으로 번역되었다. Park 등(2016)의 연구에서 한국인 구강암과 환자를 대상으로 SHI 한국어 번안판의 타당도와 신뢰도를 검증하였다. 구강암 환자의 SHI는 말명료도와 강한 음의 상관관계를 보이므로 환자의 개인의 말 기능을 측정할 뿐만 아니라 말 문제에 대한 인식을 평가할 수 있다고 보고되었다 (Degroote, Simon, Borel, \& Crevier-Buchman, 2012). 구강암 환자 외에도 구개열 환자에게 SHI를 적용하여 말장애 인식을 확인한 바 있다(Schönmeyr et al., 2015).

이에 본 연구에서는 SHI를 통해 파킨슨병 환자의 말장애에 대한 인식을 파악하고, 이러한 검사도구가 파킨슨병 환자의 말 문제를 측정하는 데 유용한지를 확인하고자 한다. 파킨슨병 환자의 $\mathrm{H} \& \mathrm{Y}$ 단계에 따라 SHI 점수도 제시하여 중증도에 따른 말 문제 인식도 알아볼 수 있을 것이다. 더불어, SHI는 말 특화된 삶의 질 도구이므 로 삶의 질을 구성하는 의사소통 능력, 인구학적 특성, 임상적 특성 을 중심으로 각 요인 간의 상관관계를 살펴보고자 한다. 의사소통 능력 측정을 위해 파킨슨병 환자의 말 특징을 대표하는 말명료도 를 사용하고자 한다. 말명료도는 말 산출의 모든 단계가 종합적으 로 반영된 것으로 개인의 구어 의사소통 능력을 가장 잘 반영하는 지표이다(Duffy, 2013). 따라서 파킨슨병 환자에게 SHI를 적용하 여 말장애 인식을 파악하고, SHI 점수와 상관관계가 있는 요인들 에 대하여 그 영향력을 확인하고자 한다. 이를 위한 구체적인 연구 문제는 다음과 같다.

1) 파킨슨병 환자의 SHI 점수는 어떠한가?

2) 파킨슨병 환자의 SHI 점수와 요인(예: 성별, 연령, 교육수준, 유 병기간, H\&Y stage, 인지기능, 우울증세, 말명료도) 간의 상관 관계는 무엇인가?
3) 파킨슨병 환자의 SHI 점수에 영향을 주는 요인(예: 성별, 연령, 교육수준, 유병기간, H\&Y stage, 인지기능, 우울증세, 말명료 도)은 무엇인가?

\section{연구방법}

\section{연구대상}

본 연구의 대상은 신경과나 재활의학과에서 파킨슨병으로 확진 된 환자 48 명(남 20 명, 여 28명)을 포함하였다(Table 1). 대상자 연령 의 평균( \pm 표준편차)은 63.44 세 $( \pm 10.26)$ (범위: 33-79세)였다. 교 육년수의 평균( \pm 표준편차)은 12.52년( \pm 3.17 ) (1-6년: 4명, 7-12년: 28 명, 13년 이상: 16 명)이었다. 발병 후 경과 기간(post onset time, $\mathrm{POT}$ )의 평균( \pm 표준편차)은 7.06년( \pm 5.40 ) (범위: 1-25년)이었다. $\mathrm{H} \& \mathrm{Y}$ 단계의 평균( \pm 표준편차)은 1.71 ( \pm 0.97 ) (stage I: 28명, stage II: 9 명, stage III: 8 명, stage IV: 3 명)이었다. 한국판 간이정신상태검 사(K-MMSE)의 평균( \pm 표준편차)은 27.81점( \pm 2.75 ) (범위: 19-30 점)이었고, 한국판 단축형 노인우울척도(GDSSF-K)의 평균( \pm 표 준편차)은 7.35점( \pm 4.32 ) (범위: 0-15점)이었다.

\section{연구방법}

연구절차

본 연구는 연세대학교 생명윤리위원회(IRB No. 7001988-201711HR-279-04)의 승인을 거쳐 진행되었으며, 사례면담, 인지기능검사, 우울검사, 설문지 작성, 말 자료 수집의 순서로 실시하였다.

Table 1. Demographic information of the Parkinson's disease subjects ( $N=48)$

\begin{tabular}{lc}
\hline Variable & Value \\
\hline Age (yr) & $63.44 \pm 10.26$ \\
Gender & \\
Men & 20 \\
Women & 28 \\
Education (yr) & $12.52 \pm 3.17$ \\
POT (yr) & $7.06 \pm 5.40$ \\
K-MMSE & $27.81 \pm 2.75$ \\
GDSSF-K & $7.35 \pm 4.32$ \\
H\&Y stage & \\
I & 28 \\
II & 9 \\
III & 8 \\
IV & 4 \\
\hline
\end{tabular}

Values are presented as mean $\pm S D$.

$\mathrm{POT}=$ post onset time; K-MMSE=Korean version of Mini-Mental State Examination (total score: 30); GDSSF-K = Geriatric Depression Scale Short Form-Korean version (total score: 15); H\&Y stage= Hoehn and Yahr stage. 
자료 수집

말장애지수(SHI)

SHI 설문지는 Park 등(2016)에 의해 한국어 번안본을 중심으로 일부 문항을 의미에 맞게 수정한 것을 사용하였다(Appendix 1). 대 상자가 직접 작성하는 것을 원칙으로 하되, 도움을 필요로 할 때는 검사자가 문항을 읽어주고 듣고 대답하도록 하였다. SHI는 총 30 개 문항으로서, 말 기능 영역(speech, 14문항)과 심리사회적 기능 영역 (psychosocial, 14문항)으로 분류되어 있으며, 재정(1문항), 말명료 도(1문항)의 2 개 문항(22번, 23번)의 경우, 하위영역에서 제외되지 만 점수의 합계에 포함된다. 이 도구는 Likert 5 점 척도로서 $(0=$ 전 혀 없다, $1=$ 거의 없다, $2=$ 가끔 있다, $3=$ 자주 있다, $4=$ 항상 있다) 평가하며 SHI 점수는 총 0 점부터 120 점 $(30 \times 4=120)$ 으로 모든 문 항의 점수를 더하여 계산하고, 점수가 높을수록 말 문제가 심각하 다고 평가한다.

말자료 수집

말 자료는 한국판 웨스턴 실어증검사(Kim \& Na, 2001)에서 '스 스로 말하기' 대화과제 일부와 건강상태 질문(예: 현재 본인의 건강 상태에 대해 어떻게 생각하세요?, 지금 생활하시거나 말씀하실 때 가장 불편한 점은 무엇인가요?)을 통해 자발화를 수집하였다. 대화 질문에 주저하거나 발화가 단답형일 경우, 세부질문(예: 구체적으 로 언제 어떻게 아픈지 말씀해주세요, 의사선생님께서는 어떻다고 말씀하셨나요? 등)을 사용하여 긴 발화를 유도하였다. 모든 절차는 복용하는 약물의 약효가 지속되는 상태(on-medication)에서 실시 하였고, 대화과제를 진행하는 동안 환자의 말을 경청하고 끊지 않 도록 주의하였다. 말 자료 수집은 조용한 환경에서 대상자와 일대 일로 진행하고 녹음기를 사용하여 수집하였다. 녹음기 마이크와 대상자의 입 사이가 10-15 cm로 일정하게 유지하도록 하였으며 wave 형식의 파일로 입력하였다.

Table 2. Speech Handicap Index (SHI) scores of the Parkinson's disease subjects ( $N=48$ )

\begin{tabular}{lcc}
\hline SHI domains & Number of items & Mean \pm SD (range) \\
\hline Total score & 30 & $41.04 \pm 25.64(0-107)$ \\
Speech & 14 & $20.90 \pm 11.93(0-49)$ \\
Psychosocial & 14 & $17.52 \pm 12.75(0-51)$ \\
\hline
\end{tabular}

Table 3. Speech intelligibility (\%) of the Parkinson's disease subjects ( $N=48$ )

\begin{tabular}{lc}
\hline & Mean \pm SD (range) \\
\hline Speech intelligibility & $73.69 \pm 26.53(4-100)$ \\
\hline
\end{tabular}

\section{자료분석}

$\mathrm{SHI}$ 는 각 환자의 점수를 합으로 총점을 산출하고, 각 하위항목 을 합으로 산출하였다. 말명료도 평가의 경우, 화자가 길게 발화할 수 있는 답변인 자발화의 '건강상태’ 주제에 해당하는 부분을 우선 선택하였다. 본 연구에서는 화자에 따라 문장 발화의 길이가 차이 가 나타날 수 있기 때문에 화자의 말명료도를 측정할 수 있는 충분 한 발화에서 20 초 동안의 자료를 분석하였다. 중간에 평가자의 음 성이나 긴 공백, 잡음의 경우에 연구자가 편집하여 사용하였다. 말 명료도 평가는 5 명의 언어치료사에게 환자들의 말 샘플을 1 회씩 들려주고 어느 정도 알아들을 수 있는지에 대해 $0 \%-100 \%$ 로 나타 내도록 하였다. 연구자는 각 환자에 대한 5 명 평가자의 말명료도 결 과를 평균치로 계산하여 백분율로 환산하였다. 평가자 간 신뢰도 평가는 언어치료사 5 명이 평가한 자료를 상관분석하였다. 평가자 내 신뢰도 평가를 위해 전체자료의 $20 \%$ 를 무작위로 선정하여 발화 샘플을 임의로 섞어 전체 평가자에게 들려준 후 상관분석하였다.

\section{통계분석}

수집된 자료에 대한 통계분석은 Statistical Product and Service Solution (SPSS version 24.0)을 사용하였으며 통계학적 검정에 의 한 유의수준은 .05로 하였다. 첫째, 파킨슨병 환자의 SHI 점수와 말 명료도 및 관련요인 간의 상관관계를 알아보기 위해 피어슨 상관 분석(Pearson correlation analysis)을 실시하였다. 또한 말명료도 평가의 평가자 간 신뢰도와 평가자 내 신뢰도를 측정하기 위해 피 어슨 상관분석을 실시하였다. 둘째, SHI 점수와 관련된 변인 간에 영향력을 알아보기 위해 다중회귀분석(multiple regression analysis)을 시행하였다.

Table 4. Correlation between the SHI and variables $(n=48)$

\begin{tabular}{lccc}
\hline \multirow{2}{*}{ Variable } & \multicolumn{3}{c}{ SHI } \\
\cline { 2 - 4 } & Total score & Speech & Psychosocial \\
\hline Gender & -.197 & -.244 & -.156 \\
Age & -.126 & -.122 & -.132 \\
Education & .070 & .068 & .064 \\
POT & .164 & .225 & .110 \\
H \& Y stage & $.342^{*}$ & $.394^{* *}$ & .282 \\
K-MMSE & -.259 & -.272 & -.223 \\
GDSSF-K & $.398^{* *}$ & $.417^{* *}$ & $.384^{* *}$ \\
Speech intelligibility & $-.710^{* *}$ & $-.722^{* *}$ & $-.681^{* *}$ \\
\hline
\end{tabular}

$\mathrm{SHI}=$ Speech Handicap Index; POT = post onset time; K-MMSE = Korean version of Mini-Mental State Examination; GDSSF-K = Geriatric Depression Scale Short FormKorean version; $\mathrm{H} \& Y$ stage $=$ Hoehn and $Y$ ahr stage.

${ }^{*} p<.05,{ }^{* *} p<.01$. 
Table 5. Multiple regression analysis of the $\mathrm{SHI}(\mathrm{N}=48)$

\begin{tabular}{|c|c|c|c|c|c|c|}
\hline & & & $B$ & $\beta$ & $p$ & $R^{2}\left(\Delta R^{2}\right)$ \\
\hline \multirow[t]{9}{*}{ SHI } & Total score & H\&Y stage & -.560 & -.021 & .855 & $.559(.529)$ \\
\hline & & GDSSF-K & 1.462 & .246 & $.028^{*}$ & \\
\hline & & Speech Intelligibility & -.638 & -.660 & $.000^{* *}$ & \\
\hline & Speech & H\&Y stage & .436 & .035 & .754 & $.585(.556)$ \\
\hline & & GDSSF-K & .684 & .248 & $.023^{*}$ & \\
\hline & & Speech Intelligibility & -.291 & -.648 & $.000^{* *}$ & \\
\hline & Psychosocial & $\mathrm{H} \& Y$ stage & -1.089 & -.083 & .496 & $.520(.488)$ \\
\hline & & GDSSF-K & .757 & .256 & $.028^{*}$ & \\
\hline & & Speech Intelligibility & -.314 & -.654 & $.000^{* *}$ & \\
\hline
\end{tabular}

SHI = Speech Handicap Index; H\&Y stage = Hoehn and Yahr stage; GDSSF-K= Geriatric Depression Scale Short Form-Korean version. ${ }^{*} p<.05,{ }^{* *} p<.01$.

\section{연구결과}

\section{$\mathrm{SHI}$ 점수}

파킨슨병 환자의 SHI 총점 평균( \pm 표준편차)은 41.04 점 $( \pm 25.64)$ (범위: 0-107)이었다. SHI의 하위영역 점수에서 말 영역 점수의 평 균( \pm 표준편차)은 20.90점( \pm 11.93 ) (범위: 0-49)이고 심리사회 영 역 점수의 평균( \pm 표준편차)은 17.52 점 $( \pm 12.75)$ (범위: 0-51)이었 다(Table 2). SHI 총점에 따른 $\mathrm{H} \& \mathrm{Y}$ 단계의 평균( \pm 표준편차)은 stage I은 31.82점( \pm 20.52$)$, stage II는 57.89점 $( \pm 23.09)$, stage III은 50.13 점 $( \pm 28.46)$, stage IV는 52.33점 $( \pm 24.90)$ 이었다.

\section{$\mathrm{SH}$ 와 말명료도 및 관련 요인 간의 상관관계 말명료도와 말명료도 평가자 신뢰도}

파킨슨병 환자의 말명료도의 평균( \pm 표준편차)은 $73.69 \%$ ( \pm 26.53$)$ (범위: 4-100)이었다. 평가자 간 신뢰도는 대화과제에서 5명의 평가 자 간의 산출된 상관계수의 평균( \pm 표준편차)은 $r=.828$ ( \pm .069$)$ (범위: .728-942)로 모두 유의한 상관관계를 보였다 $(p<.01)$. 평가자 내 신뢰도는 전체 자료에서 $20 \%$ 의 동일한 발화 샘플을 임의로 섞 어 평가하였다. 상관계수의 평균( \pm 표준편차)은 $r=.916( \pm .070)$ (범위: .806-.975)으로서 모두 유의한 상관관계가 나타났다 $(p<.01)$ (Table 3). H\&Y 단계에 따른 말명료도의 평균( \pm 표준편차)은 stage $\mathrm{I}$ 은 82.52점( \pm 17.74$)$, stage II는 70.07점( \pm 25.90$)$, stage III은 51.75 점 $( \pm 33.79)$, stage $\mathrm{IV}$ 는 60.67 점 $( \pm 30.35)$ 이었다.

\section{$\mathrm{SH}$ 와 말명료도 및 관련요인 간의 상관관계}

$\mathrm{SHI}$ 총점과 상관관계가 나타난 요인은 $\mathrm{H} \& \mathrm{Y}$ 단계 $(r=.342)$, 우울 증세 $(r=.398)$, 말명료도 $(r=-.710)$ 였다. SHI 하위영역인 말 기능 점 수와 상관관계가 나타난 요인은 $\mathrm{H} \& \mathrm{Y}$ 단계 $(r=.394)$, 우울증세 $(r=.417)$, 말명료도 $(r=-.722)$ 였다. SHI 하위영역인 심리사회기능 점수와 상관관계가 나타난 요인은 우울증세 $(r=.384)$, 말명료도 $(r=.-681)$ 였다. 따라서 SHI 총점 및 하위영역과 상관관계가 나타난 요인은 말명료도, 우울증세, H\&Y 단계였다(Table 4).

\section{$\mathrm{SH}$ 의 영향 요인}

상관분석에서 유의한 상관관계가 나타난 $\mathrm{H} \& \mathrm{Y}$ 단계, 우울증세, 말명료도가 SHI 총점 및 하위영역에 미치는 영향을 알아보기 위하 여 다중회귀분석을 실시하였다. SHI의 총점 및 하위영역에 영향력 을 주는 요인은 말명료도 $(p<.01)$ 와 우울증세 $(p<.05)$ 였다(Table 5). 이는 말명료도가 낮을수록 $(B=-.638, B=-.291, B=-.314)$, 그리 고 우울증세가 높을수록 $(B=1.462, B=.684, B=.757)$ 말 문제가 심하다고 느낀다는 것을 의미한다.

말명료도와 우울증세에 대하여 본 회귀모형은 $\mathrm{SHI}$ 의 총 점수에 서 약 $55.9 \%$ 의 설명력을 보였다 $\left(\mathrm{R}^{2}=.559\right)$. $\mathrm{SHI}$ 의 말 점수에서 말명 료도와 우울증세에 대하여 약 $58.5 \%\left(\mathrm{R}^{2}=.585\right), \mathrm{SHI}$ 의 심리사회 점수에서 약 $52.0 \%$ 의 설명력을 가졌다 $\left(\mathrm{R}^{2}=.520\right)$.

\section{논의 및 결론}

최근 들어 환자의 삶의 질에 관심이 늘어남에 따라, 환자 중심의 평가가 중요해졌다(Den Oudsten et al., 2007). 파킨슨병 환자들은 자기보고 형식의 설문지를 통해 보행장애(Curtze, Nutt, CarlsonKuhta, Mancini, \& Horak, 2016), 삼킴장애(Plowman-Prine et al., 2009), 음성장애(Guimaraes, Cardoso, Pinto, \& Ferreira, 2017) 등 에 장애를 인식한다고 보고하였다. 그러나 말 문제에서는 환자 호 소 중심의 사례만 있을 뿐 도구를 통한 연구는 부족한 실정이다. 본 연구에서는 SHI를 통해 파킨슨병 환자의 말 문제 인식을 확인하고, 
$\mathrm{SHI}$ 점수에 영향을 미치는 요인을 확인하였다. 본 연구의 주요 결 과 및 그에 따른 논의점은 다음 세 가지를 들 수 있다.

첫째, 파킨슨병 환자에게 $\mathrm{SHI}$ 를 적용한 결과, 총 48 명의 파킨슨 병 환자들 중 45 명(93.8\%)의 SHI 총점이 선행연구(Park et al., 2016) 에서 보고된 정상노인 통제군의 평균치(평균 \pm 표준편차: .5土.6) 를 훨씬 상회함으로써, 환자 스스로의 말장애 인식 정도가 상당히 높은 것으로 판단되었다. 이들 환자들은 파킨슨병으로 인해, 호흡, 발성, 조음, 운율 모든 하부 영역의 말 산출이 저하되었고(Jung, Cho, $\mathrm{Kim}, \& \mathrm{Kim}, 2011)$, 특히 낮은 말명료도가 환자의 삶의 질에 영향 을 미쳐 이에 대한 말장애 인식이 높아진 것으로 풀이된다(Dykstra et al., 2007). 파킨슨병 환자들은 발병 초기부터 보이는 음성장애에 대해서도 음성장애지수(Voice Handicap Index, VHI)를 통해 높 은 인식을 확인할 수 있기도 한다(Frost, Tripoliti, Hariz, Pring, \& Limousin, 2010).

두 번째 결과 및 논의점으로는, 파킨슨병 환자는 $\mathrm{H} \& \mathrm{Y}$ 단계, 즉 중증도가 높을수록 SHI 점수가 높아진다는 것이다. H\&Y 단계는 파킨슨병 환자의 운동 및 자세에 따라 전문가가 중증도를 측정하 는 것이다(Hoehn \& Yahr, 1967). 이로써, 파킨슨병 환자의 신체적 증상이 심하게 나타날수록 말운동 장애가 악화되며 동시에 환자의 말장애에 대한 인식의 정도도 높아지는 것으로 해석된다. 실제 본 연구결과에서도 H\&Y 단계가 stage III, IV인 환자의 말명료도가 stage I, II의 환자들보다 낮았다. 따라서 본 연구결과를 통해 전문가 가 측정한 중증도와 환자 본인이 받아들이는 장애의 정도가 유사 함을 알 수 있었다. 한편, 파킨슨병 환자들은 H\&Y 단계가 높아질수 록 말장애에 대한 인식도뿐만 아니라 음성장애지수인 VHI 점수를 통해 음성장애에 대한 인식도 역시 높아짐이 보고된 바 있다(Degroote et al., 2012). 또한, $\mathrm{H \& Y}$ 단계가 높아질수록 파킨슨병 환자들 의 삶의 질 점수(PDQ-39) 역시 낮아졌다(Muslimovic et al., 2008).

한편, 본 연구 대상자들의 H\&Y 단계가 대부분 I 혹은 II로 낮은 편임에도 불구하고 선행연구(Park et al., 2016)의 노인 통제군보다 높았다는 점은 주목할만한 결과이다. 더욱이, stage II의 환자의 $\mathrm{SHI}$ 점수는 본 연구의 전체 환자의 총점 평균과 비교하였을 때도 높은 점수를 보였다. 비교적 경증의 파킨슨병 환자들조차 말장애 를 호소하고, 심각하다고 인식한다는 점은 환자에 대한 평가 및 중 재 시 중증도가 낮은 환자들의 말 문제가 간과되어서는 안 된다는 것을 시사한다. 파킨슨병 환자에게 PDQL, PDQ-39, SF-36을 적용 한 결과에서도 $\mathrm{H} \& \mathrm{Y}$ 단계 I 혹은 II인 환자의 삶의 질이 낮았는데 (Muslimovic et al., 2008), 이는 파킨슨병 환자의 음성측면에서도 중증도에 상관없이 경도의 파킨슨병 환자가 음성문제를 보였기 때 문이다(Holmes, Oates, Phyland, \& Hughes, 2000).
세 번째 결과 및 논의점은, SHI 점수에 영향을 미친 변인으로서 말명료도와 우울증세를 들 수 있다는 것이다. 먼저, 파킨슨병 환자 의 말명료도가 낮을수록 SHI 점수가 높아졌는데, 이는 본인의 말 명료도 정도를 환자 스스로 정확하게 인식하였다는 것을 의미한 다. 파킨슨병 환자 외에도 구강암 환자(Park et al., 2016), 구개열 환 자(Schönmeyr et al., 2015)도 SHI를 적용하여 말장애 인식을 확인 하였다. 특히, 구강암 환자의 경우 말명료도가 낮을수록 SHI 점수 가 높아져 SHI를 통해 환자 중심의 말 기능을 평가할 수 있다(Park et al., 2016). 이와 더불어, SHI의 하위영역 점수에도 말명료도가 영 향을 주었다. 먼저, 말 기능 점수에서는 말명료도와 관련한 문항이 포함되어 있어 강한 상관성이 있었다. 또한 SHI가 말(Speech) 특화 된 도구이므로 환자의 말 특성을 더 반영한 것으로도 볼 수 있다. 상기 결과에서 주목할 점은 말명료도가 심리사회적 기능 점수에도 영향을 주었다는 점이다. 파킨슨병 환자의 낮은 말명료도는 직장 동료나 친구 등 사람 간의 관계를 불편하게 만들어 개인의 심리적, 정서적, 사회 환경적 측면까지 영향을 미친다는 연구(Dykstra et al., 2007)로 설명될 수 있다.

또한, 파킨슨병 환자의 약 40-70\%는 우울증세가 나타난다고 보 고되고 있어 우울증 요인은 중요하다고 할 수 있다(Cummings, 1992). 본 연구의 파킨슨병 환자들은 우울증세가 심할수록 말 문제 를 심각하게 여겼는데, 파킨슨병 환자가 우울증세가 있는 경우 삶 의 질이 유의하게 낮다고 보고된다(Dykstra et al., 2007). 우울증세 가 삶의 질에 큰 영향을 주는 이유는 삶의 질 척도와 우울증은 개 인의 심리상태를 반영하기 때문에 동일한 영역을 측정한다고 볼 수 있다(Rahman, Griffin, Quinn, \& Jahanshahi, 2008). 더불어, 우울 증세는 SHI의 하위영역인 말 기능 점수와 심리사회적 기능 점수에 서도 유의한 음의 상관관계를 보였다. 우울증세는 파킨슨병 환자의 비운동성 증상(non-motor symptoms) 중 하나로 심리사회적 기능 점수에 상관성을 보인 것으로 판단된다(Fahn, 2003). 말 기능 점수 에 관련이 있다는 점은 선행연구에서 파킨슨병 환자의 우울증세가 말 문제에 영향을 미쳤다는 결과가 있으며(Sapir, 2014), 파킨슨병 환자 외에도 생물학적으로 우울증세가 있는 환자들은 말 문제가 두드러진다고 판명된 바 있다. 우울증에 따라 비정상적인 운율, 단 음량, 단음도, 느린 속도, 부적절한 쉼이 나타난다고 보고된다(Darby, Simmons, \& Berger, 1984). 따라서 파킨슨병 환자의 우울증세 가 말 문제 악화에 영향을 끼치며 더불어 말 문제 인식에 영향을 준 다는 것을 확인하였다. 이에 우울증세에 따라 파킨슨병 환자의 말 호소에 대한 해석을 주의하여야 함을 알 수 있었다.

본 연구의 의의는 파킨슨병 환자들에게 최초로 $\mathrm{SHI}$ 를 적용하여 파킨슨병 환자의 말장애 인식을 확인하였다는 점이다. 파킨슨병 환 
자에 대한 평가 시, 환자 자신의 문제 의식에 대한 인식 정도를 확인 하는 수단으로 $\mathrm{SHI}$ 를 사용할 수 있으며 이에 대한 정보를 임상가 에게 제공할 수 있을 것이다. 본인의 말장애에 대한 인식이 파킨슨 병 중증도가 낮은 환자에서도 높게 측정됨에 따라, 파킨슨병 초기 부터 말 문제에 대한 적절한 평가와 중재가 필요하다는 시사점을 제시한다.

\section{REFERENCES}

Cummings, J. L. (1992). Depression and Parkinson's disease: a review. The American Journal of Psychiatry, 149, 443-454.

Curtze, C., Nutt, J. G., Carlson-Kuhta, P., Mancini, M., \& Horak, F. B. (2016). Objective gait and balance impairments relate to balance confidence and perceived mobility in people with Parkinson disease. Physical Therapy, 96, 1734-1743.

Darby, J. K., Simmons, N., \& Berger, P. A. (1984). Speech and voice parameters of depression: a pilot study. Journal of Communication Disorders, 17, 75-85.

Darley, F. L., Aronson, A. E., \& Brown, J. R. (1969). Clusters of deviant speech dimensions in the dysarthrias. Journal of Speech, Language, and Hearing Research, 12, 462-496.

Degroote, G., Simon, J., Borel, S., \& Crevier-Buchman, L. (2012). The French version of Speech Handicap Index: validation and comparison with the voice handicap index. Folia Phoniatrica et Logopaedica, 64, 20-25.

Den Oudsten, B. L., Van Heck, G. L., \& De Vries, J. (2007). Quality of life and related concepts in Parkinson's disease: a systematic review. Movement Disorders, 22, 1528-1537.

Duffy, J. R. (2013). Motor speech disorder (3nd ed.). St. Louis, MO: Elsevier.

Dykstra, A. D., Hakel, M. E., \& Adams, S. G. (2007). Application of the ICF in reduced speech intelligibility in dysarthria. Seminars in Speech and Language, 28, 301-311.

Fahn, S. (2003). Description of Parkinson's disease as a clinical syndrome. Annals of the New York Academy of Sciences, 991, 1-14.

Ferguson, S. H. (2012). Talker differences in clear and conversational speech: vowel intelligibility for older adults with hearing loss. Journal of Speech, Language, and Hearing Research, 55, 779-790.

Frost, E., Tripoliti, E., Hariz, M. I., Pring, T., \& Limousin, P. (2010). Self-perception of speech changes in patients with Parkinson's disease following deep brain stimulation of the subthalamic nucleus. International Journal of Speech-Language Pathology, 12, 399-404.
Guimaraes, I., Cardoso, R., Pinto, S., \& Ferreira, J. J. (2017). The psychometric properties of the voice handicap index in people with Parkinson's disease. Journal of Voice, 31, 258.e13-258.e18.

Hartelius, L., \& Svensson, P. (1994). Speech and swallowing symptoms associated with Parkinson's disease and multiple sclerosis: a survey. Folia Phoniatrica et Logopaedica, 46, 9-17.

Hoehn, M. M., \& Yahr, M. D. (1967). Parkinsonism: onset, progression and mortality. Neurology, 17, 427-442.

Holmes, R. J., Oates, J. M., Phyland, D. J., \& Hughes, A. J. (2000). Voice characteristics in the progression of Parkinson's disease. International Journal of Language \& Communication Disorders, 35, 407-418.

Jaywant, A., \& Pell, M. D. (2010). Listener impressions of speakers with Parkinson's disease. Journal of the International Neuropsychological Society, 16, 49-57.

Jung, E., Cho, S. R., Kim, Y., \& Kim, H. (2011). Characteristics of diadochokinesis in hypokinetic dysarthria: rate and regularity. Korean Journal of Communication \& Disorders, 16, 74-82.

Kim, H., \& Na, D. (2001). Paradise · Korean version-Western Aphasia Battery $(P \cdot K-W A B)$. Seoul: Paradise Institute for Children with Disabilities.

Miller, N., Noble, E., Jones, D., \& Burn, D. (2006). Life with communication changes in Parkinson's disease. Age and Ageing, 35, 235-239.

Muslimović, D., Post, B., Speelman, J. D., Schmand, B., de Haan, R. J., \& Group, C. S. (2008). Determinants of disability and quality of life in mild to moderate Parkinson disease. Neurology, 70, 2241-2247.

Park, S. S., Choi, S. H., Hong, J. A., Hong, Y. H., Jeong, N. G., Lee, S. Y., ... \& Hah, J. H. (2016). Validity and reliability of the Korean version of the Speech Handicap Index in patients with oral cavity cancer. International Journal of Oral and Maxillofacial Surgery, 45, 433-439.

Plowman-Prine, E. K., Sapienza, C. M., Okun, M. S., Pollock, S. L., Jacobson, C., Wu, S. S., \& Rosenbek, J. C. (2009). The relationship between quality of life and swallowing in Parkinson's disease. Movement Disorders, 24, 13521358.

Rahman, S., Griffin, H. J., Quinn, N. P., \& Jahanshahi, M. (2008). Quality of life in Parkinson's disease: the relative importance of the symptoms. Movement Disorders, 23, 1428-1434.

Rinkel, R. N., Leeuw, I. M., van Reij, E. J., Aaronson, N. K., \& Leemans, C. R. (2008). Speech Handicap Index in patients with oral and pharyngeal cancer: better understanding of patients' complaints. Head \& Neck, 30, 868-874.

Sapir, S. (2014). Multiple factors are involved in the dysarthria associated with Parkinson's disease: a review with implications for clinical practice 
Hyo Jin Mun, et al. • Speech Handicap Index in Parkinsonian Patients

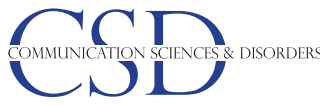

and research. Journal of Speech, Language, and Hearing Research, 57, 1330-

1343.

Schönmeyr, B., Wendby, L., Sharma, M., Jacobson, L., Restrepo, C., \& Camp- bell, A. (2015). Speech and speech-related quality of life after late palate repair: a patient's perspective. Journal of Craniofacial Surgery, 26, 1513-1516. 
Appendix 1. Items of the Speech Handicap Index (SHI)

\section{Speech Handicap Index (Korean version)}

$0=$ 전혀 없다 $1=$ 거의 없다 $2=$ 가끔 있다 $3=$ 자주 있다 $4=$ 항상 있다

\begin{tabular}{|c|c|c|c|c|c|}
\hline 1) 사람들은 내 말을 이해하기 어려워한다. & 0 & 1 & 2 & 3 & 4 \\
\hline 2) 나는 말할 때 숨이 찬다. & 0 & 1 & 2 & 3 & 4 \\
\hline 3) 나의 말 정확도(명료도) 하루에도 몇 번씩 변한다. & 0 & 1 & 2 & 3 & 4 \\
\hline 4) 나는 말 때문에 무능력하게 느껴진다. & 0 & 1 & 2 & 3 & 4 \\
\hline *5) 사람들은 왜 내 말이 이해하기 어려운지를 내게 물어본다. & 0 & 1 & 2 & 3 & 4 \\
\hline 6) 사람들이 나에게 다시 말해달라고 하면 짜증이 난다. & 0 & 1 & 2 & 3 & 4 \\
\hline 7) 나는 전화사용을 피한다. & 0 & 1 & 2 & 3 & 4 \\
\hline 8) 나는 말 때문에 다른 사람과 대화할 때 긴장한다. & 0 & 1 & 2 & 3 & 4 \\
\hline 9) 나는 발음이 부정확하다. & 0 & 1 & 2 & 3 & 4 \\
\hline 10) 사람들은 시끄러운 곳에서 내 말을 이해하기 어려워한다. & 0 & 1 & 2 & 3 & 4 \\
\hline 11) 대화 시 말 문제 때문에 사람들이 많은 상황을 피하는 경향이 있다. & 0 & 1 & 2 & 3 & 4 \\
\hline 12) 사람들은 내 말을 귀에 거슬려 하는 듯하다. & 0 & 1 & 2 & 3 & 4 \\
\hline 13) 마주보고 대화할 때, 사람들은 나에게 되물어 본다. & 0 & 1 & 2 & 3 & 4 \\
\hline 14) 나는 말의 문제로 인해 친구, 이웃 혹은 친척들과 말을 덜하게 된다. & 0 & 1 & 2 & 3 & 4 \\
\hline *15) 나는 말할 때 힘을 줘서 말해야 할 것 같다. & 0 & 1 & 2 & 3 & 4 \\
\hline$\left.{ }^{*} 16\right)$ 다른 사람들은 나의 말 문제를 이해하기 못하는 것 같다. & 0 & 1 & 2 & 3 & 4 \\
\hline 17) 나는 말 문제로 인해 개인 및 사회생활에 제한을 받는다. & 0 & 1 & 2 & 3 & 4 \\
\hline 18) 말하기 전에 얼마나 정확하게 할지에 대해 예상하기 힘들다. & 0 & 1 & 2 & 3 & 4 \\
\hline *19) 나는 말 문제 때문에 대화에서 소외감을 느낀다. & 0 & 1 & 2 & 3 & 4 \\
\hline 20) 나는 말을 정확하게 하기 위해 노력을 한다. & 0 & 1 & 2 & 3 & 4 \\
\hline 21) 저녁이 되면 말소리가 더 나빠진다. & 0 & 1 & 2 & 3 & 4 \\
\hline 22) 나는 말 문제로 인해 수입이 줄었다. & 0 & 1 & 2 & 3 & 4 \\
\hline 23) 나는 말소리를 정확히 내려고 노력한다. & 0 & 1 & 2 & 3 & 4 \\
\hline 24) 나는 말 문제 때문에 화가 난다. & 0 & 1 & 2 & 3 & 4 \\
\hline 25) 나는 말 때문에 외부 활동을 덜 한다. & 0 & 1 & 2 & 3 & 4 \\
\hline 26) 내가 집에서 가족들을 부를 때, 가족들은 잘 알아듣지 못한다. & 0 & 1 & 2 & 3 & 4 \\
\hline 27) 나는 말 문제 때문에 장애나 결함이 있다고 느껴진다. & 0 & 1 & 2 & 3 & 4 \\
\hline 28) 나는 말 문제 때문에 대화를 계속(지속)하기 어렵다. & 0 & 1 & 2 & 3 & 4 \\
\hline 29) 나는 사람들이 다시 말해달라고 하면 당혹스럽다. & 0 & 1 & 2 & 3 & 4 \\
\hline 30) 나는 말 문제로 인해 수치심을 느낀다. & 0 & 1 & 2 & 3 & 4 \\
\hline
\end{tabular}

*Revised translation from the version of Park et al. (2016): 5, 15, 16, 19 


\section{국문초록}

\section{파킨슨병 환자에 대한 말장애지수(Speech Handicap Index)의 적용}

문효진 ${ }^{1} \cdot$ 조성래 ${ }^{2} \cdot$ 최성희 ${ }^{3} \cdot$ 김향희 ${ }^{12}$

${ }^{1}$ 연세대학교 대학원 언어병리학협동과정, ${ }^{2}$ 연세대학교 의과대학 재활의학교실, ${ }^{3}$ 대구가톨릭대학교 언어청각치료학과

배경 및 목적: 대부분의 파킨슨병 환자들은 본인들의 말 문제를 스스로 인식하므로, 그로 인해 좌절감, 무능감을 느끼고 삶의 질이 저 하된다. 국내외적으로 파킨슨병 환자의 일반적인 삶의 질에 관한 다양한 연구가 이루어지고 있지만 파킨슨병 환자의 말 문제에 특화된 삶의 질 연구는 그리 많지 않다. 방법: 본 연구는 파킨슨병 환자 48명을 대상으로 말장애지수(Speech Handicap Index, SHI)를 적용하 여 말장애에 따른 삶의 질을 조사하였다. 또한 SHI와 말명료도를 비롯한 여러 요인 간의 상관관계분석을 통해 SHI에 영향을 주는 요인 을 알아보았다. 결과: 총 48 명의 환자들 중 45 명 $(93.8 \%)$ 의 SHI 총점이 선행연구의 정상노인 통제군의 평균 \pm 표준편차. $.5 \pm .6)$ 를 훨씬 상회함으로써 대다수의 파킨슨병 환자들 스스로가 말장애를 인식함을 확인하였다. 또한, 파킨슨병 환자의 SHI 점수는 말명료도와음 의 상관관계를, 우울증세, 중증도와 양의 상관관계를 보였다. 다중회귀분석 결과에서는 SHI에 영향을 미치는 요인은 말명료도와 우울 증세였다. 논의 및 결론: 본 연구는 파킨슨병 환자들에게 최초로 $\mathrm{SHI}$ 를 적용하여 그들의 말장애에 대한 인식을 확인하였음에 의의가 있다. 본 연구의 대상자가 대부분 파킨슨병 중증도 $\mathrm{H \& Y}$ 단계 I 또는 II임에도 불구하고 높은 SHI 점수(즉, 말장애 인식도)를 나타내므 로 파킨슨병 발병 초기 단계부터 말 문제에 주의를 기울여 평가 및 중재에 적용할 필요가 있음을 시사한다.

핵심어: 말장애지수(SHI), 파킨슨병, 삶의 질, 말명료도, 우울증세, H\&Y 단계

\section{참고문헌}

김향희, 나덕렬. (2001). 파라다이스·한국판-웨스턴 실어증 검사. 서울: 파라다이스복지재단.

정은영, 조성래, 김윤정, 김향희(2011). 운동감소형 마비말장애의 조음교대운동 특성: 속도 및 규칙성. 언어청각장애연구, 16, 74-82. 